\title{
The Development of Linear Generator System Combined with Magnetic Damping Function
}

\author{
Yasuaki Sakamoto Member (Railway Technical Research Institute, ysakamo@rtri.or.jp) \\ Toshiaki Murai Member (Railway Technical Research Institute, tmurai@rtri.or.jp) \\ Takayuki Kashiwagi Member (Railway Technical Research Institute, gintyo@ rtri.or.jp) \\ Minoru Tanaka Member (Railway Technical Research Institute, m-tanaka@rtri.or.jp) \\ Erimitsu Suzuki Non-member (Railway Technical Research Institute, esuzuki@rtri.or.jp) \\ Katsuya Yamamoto Non-member （Railway Technical Research Institute, katsu@ @rtri.or.jp)
}

Keywords: superconducting Maglev system, magnetic damping, linear generator, zero-phase current, vehicle running test

The superconducting Maglev system suspended by electro dynamic suspension (EDS) intrinsically has very small magnetic damping. Therefore, analysis and simulation have been repeated to improve damping characteristics. However, the technique to use damping coils has not been applied to actual Maglev vehicles, because it is not practical to install damping coils in the limited gap space under a number of restrictions. On the other hand, it is desirable for Maglev vehicles that levitate and run at high speed to be supplied with power from the ground without contact. If an onboard generating system is adopted instead, it must be lightweight and non-polluting.

As one solution, a linear generator system was developed to collect power without contact by using harmonic magnetic fields generated by the current induced in levitation coils during levitated vehicle runs (Fig. 1). This device has not only a power collecting function but also the advantage of adding magnetic damping between the bogies and ground by controlling the current in the generator coil.

Recently, by improving the dimensions and arrangement of generator coils, and the PWM converter and its controlling methods, a linear generator system using zero-phase current control was developed that can generate damping forces more effectively than the conventional system. We installed this device on an actual Maglev vehicle and tested the power collecting function and the effect of bogie vibration control using the generated damping forces.

Fig. 2 shows a diagram of test equipment. The PWM converter converts AC power from the generator coil into DC power and supplies it to on-board loads, to serve as the power collecting function.

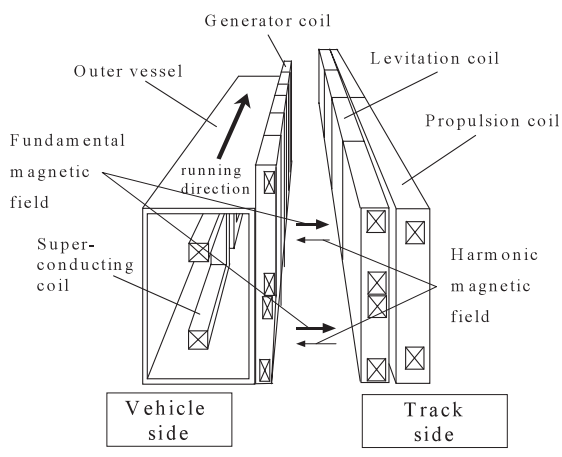

Fig. 1. Structure of linear generator
On the other hand, the PWM converter superposes zero-phase current on the AC side of a generator circuit according to signals sent from accelerometers mounted on the bogie, to serve as the bogie vibration control function.

Vehicle running tests demonstrated that the induced voltage of the generator coil approximately agrees with the calculated value, that the PWM converter runs steadily during levitated vehicle runs, and that the bogie vibration control can reduce the bogie vibration acceleration to about $40 \%$ (see Fig. 3). It is proved experimentally that the linear generator system is practical as an on-board power source and useful as a damping device for bogie vibration.

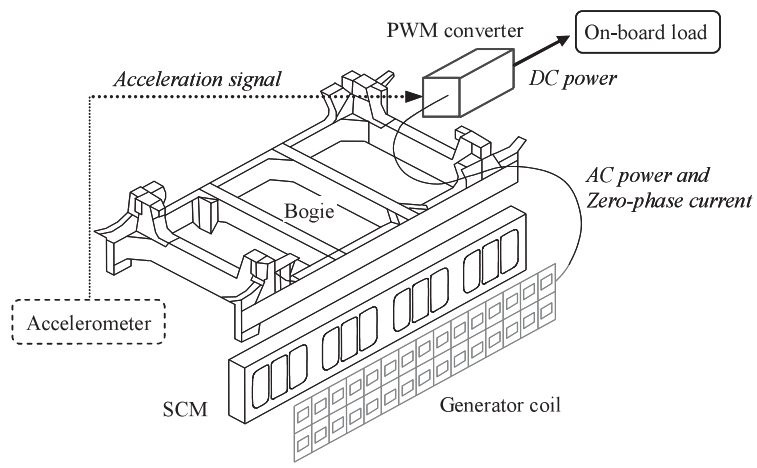

Fig. 2. Arrangement of test linear generator system

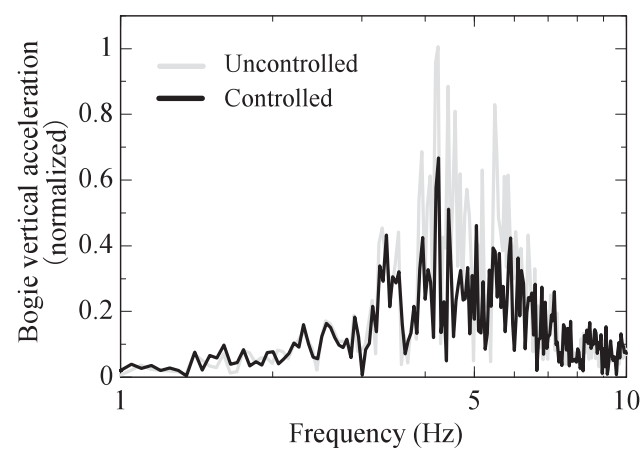

Fig. 3. Effect of vibration control 


\title{
磁気ダンピング機能を付加した誘導集電システムの開発
}

\author{
正 員 坂本 泰明* 正 員 村井 敏昭* \\ 正員柏木 隆行* 正 員 田中実* \\ 非会員 鈴木江里光* 非会員 山本 克也*
}

\section{The Development of Linear Generator System Combined with Magnetic Damping Function}

\author{
Yasuaki Sakamoto*, Member, Toshiaki Murai*, Member, Takayuki Kashiwagi*, Member, \\ Minoru Tanaka*, Member, Erimitsu Suzuki*, Non-member, Katsuya Yamamoto*, Non-member
}

In the superconducting Maglev system, a method for providing on-board service power is one of the most important subjects of technological development. As a solution, a linear generator is being developed that can collect power without contact by utilizing the harmonic magnetic field of ground coils. It can also generate electromagnetic force between the superconducting magnets and ground coils by controlling the current in the generator coils. By using this controllable electromagnetic force, it becomes possible to add magnetic damping to the electrodynamic levitation system, which is characterized by an intrinsically very small damping force. This paper describes the results of the vehicle running tests of the linear generator using zero-phase current control, combined with a magnetic damping function.

キーワード：超電導磁気浮上式鉄道, 磁気ダンピング, 誘導集電, 零相電流, 現車試験

Keywords: superconducting Maglev system, magnetic damping, linear generator, zero-phase current, vehicle running test

\section{1. はじめに}

超電導磁気浮上式鉄道の台車〜地上間のサスペンション (一次系サス) である誘導式磁気浮上は, その本質的なダン ピングが小さいことから，過去にダンピング特性向上に関 して多くの解析やシミュレーションによる検討がなされて きた。しかし，制約条件の厳しい実空隙に新たなダンピン グ専用コイルを置くことは現実的ではなく, 実機に適用さ れることが無かった。実際の車両では車体〜台車間のダン パ（二次系サス）により台車振動が過大となることはない が，一次系サスの共振周波数付近においてはこのダンパの 効果が殆ど期待できないため, 乗り心地向上の観点からは 更なる一次系サスの検討が望まれている。

一方, 高速 ·浮上走行を実現する浮上式鉄道車両の車上 電源確保について, 地上からの集電によりこれを行う場合 は高速・浮上走行に供する必要性から地上設備と非接触で あることが望まれ，又，車上での発電や蓄電による場合に おいても軽量且つ排気ガス等のない低環境負荷な電源が要 求される。

筆者らはこれら要求に同時に応える装置として, 浮上コ

* 財団法人 鉄道総合技術研究所

T 185-8540 国分寺市光町 2-8-38

Railway Technical Research Institute

2-8-38, Hikari-cho, Kokubunji 185-8540
イルの誘導電流が発生する磁界の高調波成分を利用して非 接触集電を行う分散型誘導集電装置 (1) の開発を行ってきた。 本装置は前述のダンピング特性検討において提案されてい るように，集電コイルの電流を制御することにより台車と 地上との間に制御可能な電磁力を付加することができ，こ れを磁気ダンピングとして利用できるという特長を有して いる(2)。電磁力発生の方法としては, 集電コイルとコンバー 夕で構成される交流回路（以下, 集電回路と呼ぶ) の力率 を制御する方法（無効電流方式）と零相電流を制御する方 法（零相電流方式）とがあり ${ }^{(3)}$, 後者の方が大きな発生力 を期待できるが，集電コイルの形状と配置，集電の為の 3 相電流とダンピングの為の零相電流制御方法などの開発要 素が多い。

分散型誘導集電の集電性能については, 無効電流方式を 用いた現車試験により実証してきた ${ }^{(4)}$ 。そこで今回は，よ り大きなダンピング効果を期待できる零相電流方式を現車 走行試験に供し, 集電性能の確認と共に磁気ダンピング効 果の検証とそれによる乗り心地向上効果の確認を行った。 本稿は磁気ダンピング機能を兼用した零相電流方式の分散 誘導集電装置の現車試験結果について報告する。

\section{2. 零相電流方式分散型誘導集電装置の概要}

〈2・1〉 原理及び構成誘導集電装置の基本構成を図 1 に示す。超電導磁気浮上式鉄道において, 台車に搭載され 


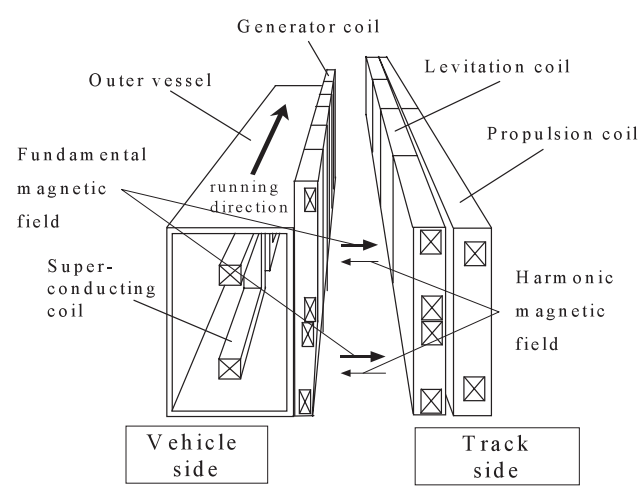

図 1 分散型誘導集電の基本構成

Fig. 1. Construction of linear generator.

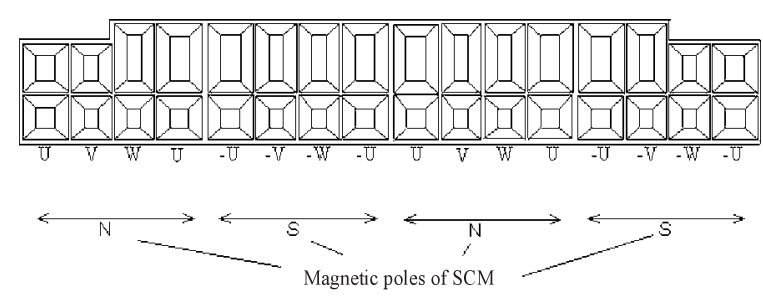

図 2 零相電流方式のコイル構成

Fig. 2. Construction of zero-phase current type coils.

た超電導磁石（SCM）はリニア同期モータの界磁として用 いられると同時に，その進行に伴う浮上コイルとの相対運 動による誘導磁気浮上・案内の磁極としても利用される。 浮上系に㧍いては，連続配置された 8 の字形状のコイル内 に電流が誘導され，超電導磁石にその極ピッチ $(\tau$ とする $)$ と同じピッチの反作用磁界が作用し浮上力を得る。ここで, 浮上コイルは独立（集中巻）に敷設されているため，上記 の反作用磁界は高調波成分を伴う。浮上コイルが $\tau / 3$ ピッ チである場合，主な高調波磁界は極ピッチが $\tau / 5$ （空間 5 次), 同期速度にある超電導磁石上で観測して時間 6 次の成 分である。ここで, 超電導磁石表面に新たに 8 の字形状の 集電コイルを配置すると，この高調波磁界から誘起電圧を 得る。これをコンバータにより力率を改善し直流電力に変 換することで電力を得ることができる。

図 2 に集電コイルの配置を示す。零相電流方式では超電 導コイルのピッチ毎にコイルを組合せ，超電導コイルの極 に合わせて逆相配置を施す。これに伴い, $\mathrm{U}$ 相と V 相 (W 相）間で巻数やコイル長を調整し，平衡に近い 3 相誘起電 圧を得られるようにしている。尚，上下コイルの高さは艤 装スペースの制約により各々異なっている。ここで，各相 に同相電流を通電すると基本波ピッチ $(\tau)$ の磁界が発生す る。これにより超電導磁石と浮上コイルの間に新たな電磁 力を発生させることができ，これを台車振動に合わせて制 御（振動制御）することで磁気ダンピングを付与すること ができる。

ここで, 図 3 に車両及び台車の上下支持系の模式図，図 4 に振動制御を併用する場合の誘導集電装置の動作説明を示

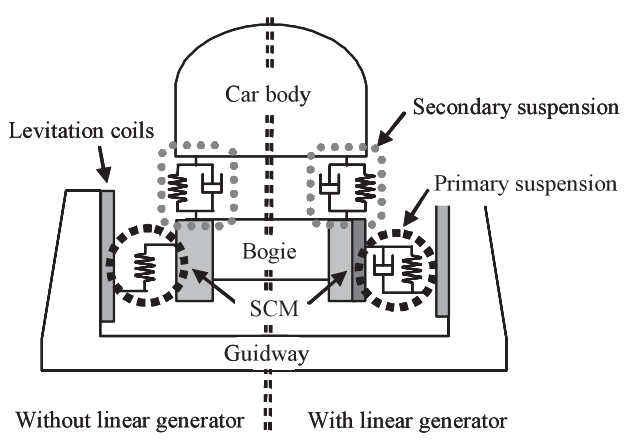

図 3 上下支持系の模式図

Fig. 3. Concept diagram of vertical suspension.

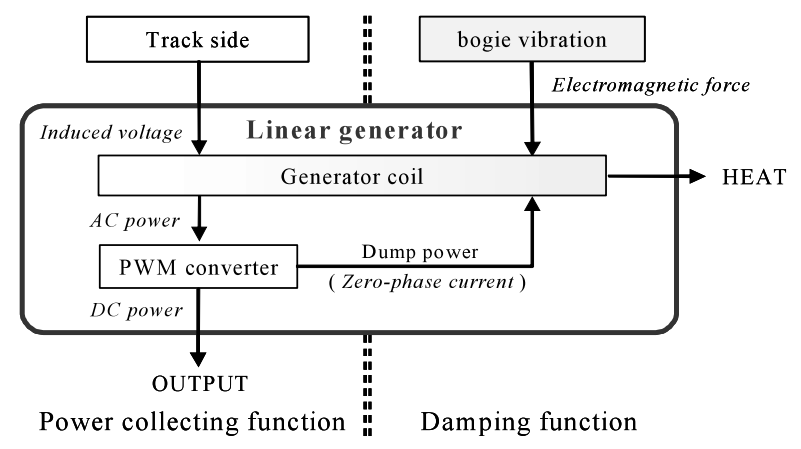

図 4 振動制御時の誘導集電装置の動作説明

Fig.4. Actuation diagram of linear generator system with damping function.

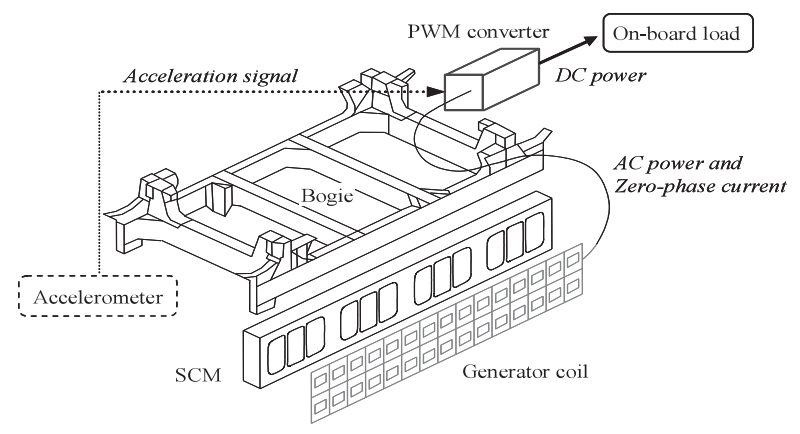

図 5 誘導集電試験装置の構成

Fig. 5. Arrangement of test linear generator system.

す。図 3 の一次系サスについて, 従来はダンパ要素が非常 に小さく, この部分の共振周波数の振動モードは二次サス のダンパを利用しても低減効果を得ることが困難であった。 誘導集電装置を用いて直接, 一次系サスにダンピング要素 を付加することで，これまで低減が困難であった振動モ一 ドを抑制し，乗り心地向上を図ることができる。

また図 4 に扔いて零相電流通電の為のエネルギーは集電 回路に誘導された電力の一部を利用するが, 設定した集電 容量に到達する速度を上回る速度域に招ける余剩電力の利 用により，見掛け上は集電能力の低下が無い。

$\langle\mathbf{2} \cdot \mathbf{2}\rangle$ 試験装置の構成図 5 に走行試験に供した零 相電流方式分散誘導集電装置の構成, 表 1 に各装置の主な 諸元，図 6 に車両に集電コイルを搭載した外観を示す。本 
表 1 試験装置の諸元

Table 1. Specifications of test equipment.

\begin{tabular}{|c|c|}
\hline $\begin{array}{l}\text { Generator coil } \\
\text { dimensions - upper, lower }\end{array}$ & $\begin{array}{l}\mathrm{U}: \quad 240 \times 450 \mathrm{~mm}, 240 \times 260 \mathrm{~mm} \\
\mathrm{~V}, \mathrm{~W}: 220 \times 450 \mathrm{~mm}, 220 \times 260 \mathrm{~mm}\end{array}$ \\
\hline number $\times$ turn & $\begin{array}{ll}\mathrm{U}: & 8 \times 17 \\
\mathrm{~V}, \mathrm{~W}: & 4 \times 26\end{array}$ \\
\hline $\begin{array}{l}\text { PWM converter } \\
\text { output }\end{array}$ & $30 \mathrm{~kW}(\max )$ \\
\hline DC voltage & $600 \mathrm{~V}$ \\
\hline Sampling frequency & $10 \mathrm{kHz}$ \\
\hline Efficiency & $90 \%$ \\
\hline
\end{tabular}

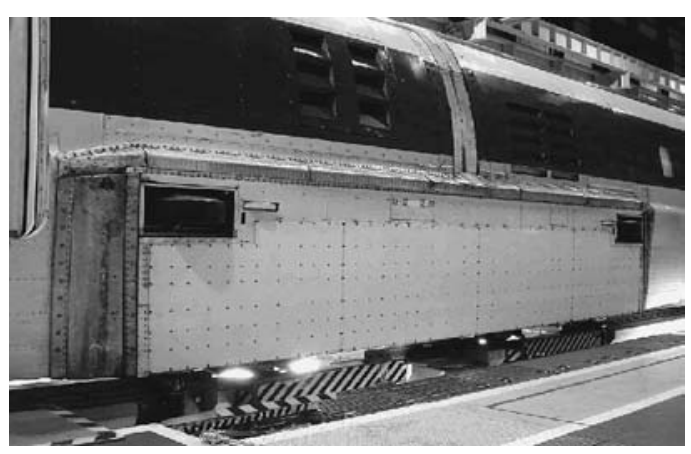

図 6 車両搭載時の集電コイルの外観

Fig. 6. Overview of generator coil installed on a bogie.
来，集電コイルは台車左右両側の超電導磁石への搭載を想 定しているが，今回の試験では片側のみとした。集電コイ ルと PWM コンバータは 3 相 6 線のケーブルで繋がれ，3 相交流電力から直流電力に変換された集電電力は車上負荷 (超電導磁石冷凍機, 空調装置, 各種制御器電源など) に供 給される。これら車上負荷の容量から装置単機当りの出力 は $25 \mathrm{~kW}$ (最大 $30 \mathrm{~kW}$ ) で設計した（台車当り 2 機搭載）。 尚, EMC 対策として主回路へのコアの㨂入やコンバー夕筐 体アース等を施した。ここで, 各機器の主な特徴を挙げる。

（1）超電導磁石 集電コイルを取付ける超電導磁石 は以前の無効電流方式で試験(4)したものを使用した。

外槽金属板の高調波磁界のシールド効果による集電コイ ルの誘起電圧低下や交流抵抗増加を低減するため, 外槽平 面不要部に凹部を設けるなどの工夫を施している。

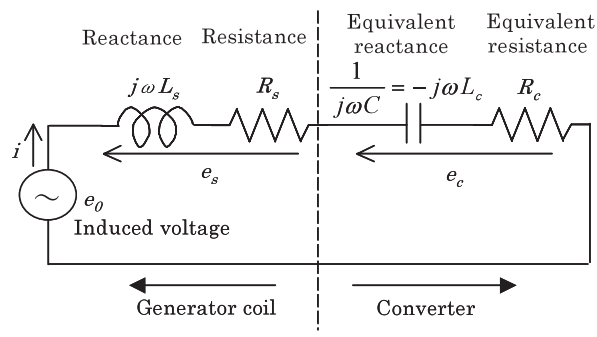

図 7 集電回路の等価回路（1 相当り）

Fig. 7. Equivalent circuit of power collection circuit.

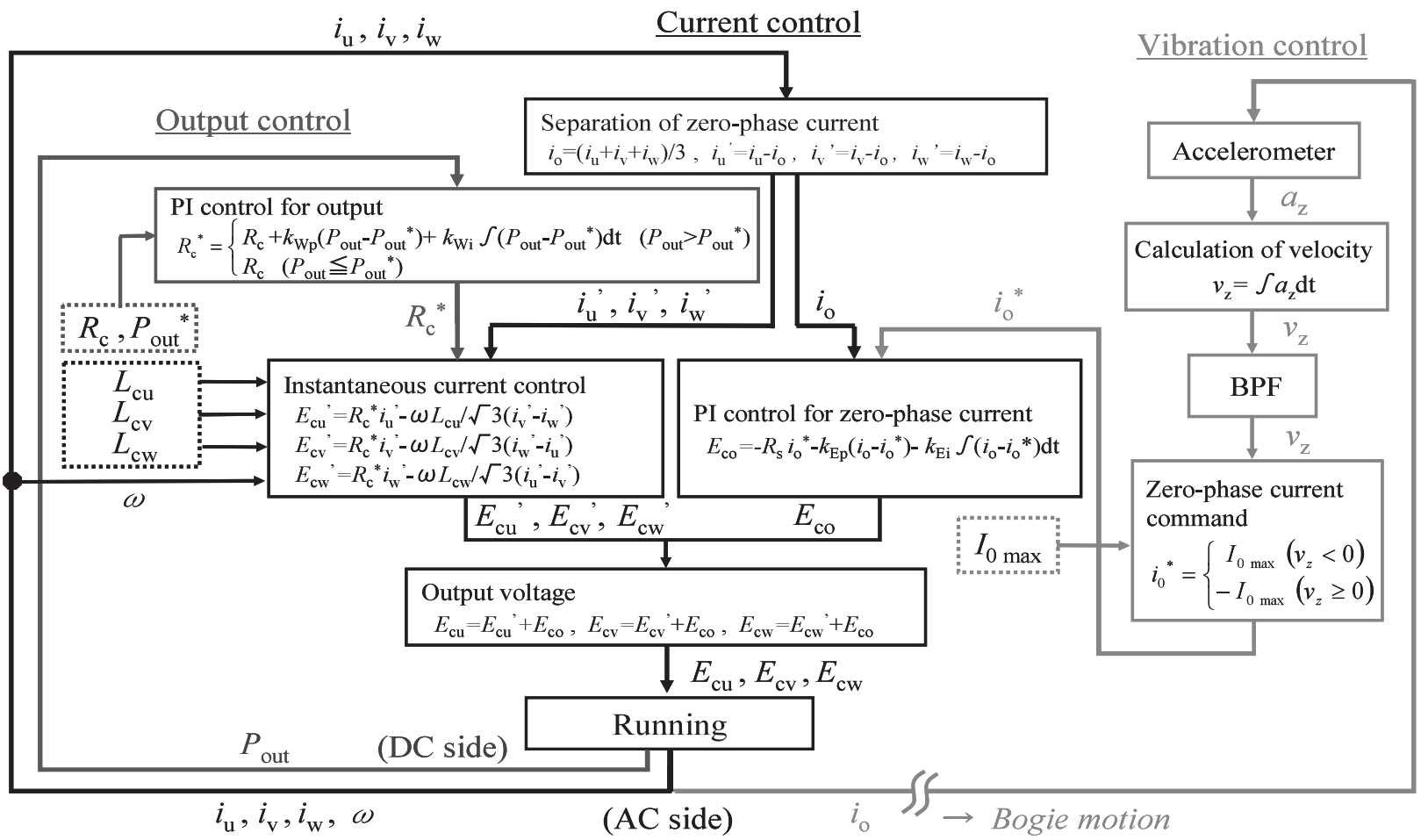

$i_{\mathrm{u}}, i_{\mathrm{v}}, i_{\mathrm{w}}$ : Instantaneous current, $\omega$ : Angular frequency, $L_{\mathrm{cu}}, L_{\mathrm{cv}}, L_{\mathrm{cw}}$ : Inductance of generator coil, $R_{\mathrm{c}}$ : Resistance of generator coil $P_{\text {out }}{ }^{*}$ : Output command, $P_{\text {out }}$ : Output, $a_{\mathrm{z}}$ : Acceleration of bogie vibration, $I_{\mathrm{o} \max }$ : Max value of zero-phase current, $k_{\mathrm{Wp}}, k_{\mathrm{Wi}}$ : Gains of PI control for output, $k_{\mathrm{Wp}}, k_{\mathrm{Ei}}$ : Gains of PI control for zero-phase current, BPF : Band pass filter

図 8 制御系の説明

Fig. 8. Block diagram of control systems. 
（2）集電コイル 集電コイル及びその取付方法は, 超 電導磁石に近接しながら高い（電流）密度で電流を流すた め大きな電磁力を受け, 且つ $500 \mathrm{~km} / \mathrm{h}$ の高速走行の風圧等 に耐える必要がありながら, 可能な限りの軽量化を図る必 要がある。構造解析などからコイルパネルを形成する構造 材（FRP）とボルト締結の適正化を図った ${ }^{(5)}$ 。また，集電 コイル自身の素線渦電流損失を低減するために，導体には ストランド線 (Litz wire) ${ }^{(6)}$ を使用した。

（3） PWM コンバータ 集電回路の不平衡インピー ダンスやリアクタンス増加に対する高力率制御, 振動制御 併用時の零相電流重畳を実現するものとして, 瞬時電流制 御 ${ }^{(7)}$ (力率を制御）と同時に発生力演算及び零相電流制御が 可能な単相 $\times 3$ 組構成の 3 相 PWM コンバータを開発した。

$\langle\mathbf{2} \cdot \mathbf{3}\rangle$ 制御系の概要 図 7 に 1 相当たりの集電回路 の等価回路を示す。また, 図 8 に制御全体の説明図を示す。 ここで簡単に各制御について述べる。

（1）瞬時電流制御 (7) 集電回路はリアクタンスが大 きく, ダイオードブリッジ等の変換器では十分な電力が得 られない。そこで力率改善策として, PWM コンバータを 用いた瞬時電流制御を開発した。これは集電コイルのリア クタンスとコンバータの等価リアクタンスとを相殺するこ とにより高力率集電動作を行うものである。このことから 図 7 では後者のリアクタンスを $-j \omega L_{\mathrm{c}}$ と表記した。本制御 の実動作を説明した図 8 の瞬時電流制御ブロック内では, 集電コイルのインダクタンスに等しくなるようにプリセッ トされたコンバータの等価インダクタンス $-L_{\mathrm{ci}}(\mathrm{i}=\mathrm{u}, \mathrm{v}, \mathrm{w})$ と, 各相の電流瞬時值とを用いて高力率集電動作に必要な 発生電圧を決定する。これにより不平衡インピーダンスを 有する集電回路に対し各相毎の高力率運転を実現する。ま た, 集電電力を制御する為にコンバー夕等価抵抗 $R_{\mathrm{c}}$ を $\mathrm{PI}$ 制御する出力制御ブロックを設けている。

（2）零相電流制御電磁力を発生させる零相電流は 後述の発生力指令部において演算される指令值 $i_{\mathrm{o}}{ }^{*}$ に追従 するようにPI 制御される。

（3）発生力指令振動制御には種々の方法が考えら れるが, 発生力を最大限利用する為, クーロン摩擦として 減衰力を発生させる凸凹制御（大きさ一定で, 振動速度に 応じて符号が決定された零相電流を出力）を行った。具体 的には図 8 の振動制御部のように台車の上下振動加速度を 積分して振動速度を演算し，バンドパスフィルタを通して 直流分及び高周波の除去を行い, 振動速度と逆方向の電磁 力を発生する零相電流最大值 $I_{0 \text { max }}$ を指令する。

尚, 本稿ではダンピング発生の為の制御について, コン バータの制御を指す場合を「零相電流制御」, 減衰力発生を 指す場合を「振動制御」と呼ぶことにする。

\section{3. 走行試験による特性確認}

〈3.1〉 試験概要集電回路のインピーダンス測定及 び外部インバータを用いた模擬誘起電圧による定置確認試 験を経て，下記の要領により走行試験を実施した。
（1）誘起電圧測定集電回路をPWM コンバータ入 力端子で開放し, 走行条件を変化させながら誘導電圧を測 定した。空力的車体揚力及び車両運動等の影響も調査した。

（2）集電性能確認 コンバー夕出力を車上電源系統 に接続した状態にて, 走行条件を様々に変化させながら集 電特性及び安定動作の確認を行った。

（3）振動制御試験集電動作を行いながら，同時に 台車振動に併せて零相電流を重畳する振動制御を実施した。 制御使用時の台車及び車両運動特性とその間の集電性能を 確認した。

\section{$\langle\mathbf{3} \cdot \mathbf{2}\rangle \quad$ 試験結果}

（1）誘起電圧測定積車条件（定員乗車重量）にお ける誘起電圧の測定值と解析值を図 9 に示す。解析值につ いては 3 次元 FEM 磁場解析 ${ }^{(8)}$ を用いており, 空力的車体 揚力（実測值）及び外槽板厚方向の渦電流を考慮した。誘 起電圧の大きさについて, 相平均值は解析值と測定值の両 者でほぼ一致した。解析值において振幅不平衡が大きかっ たが，測定值では最大 4\%以内であった。位相不平衡につ いては U-V, W-U 相間で $123 \pm 1 \mathrm{deg}$. 程度であり, ほぼ計 算結果と一致した。図 10 に測定值における誘起電圧をべ クトル図で示す。ほぼ対称 3 相電圧となっていることが確 認できる。

零相電流方式の集電コイルは，零相電流による磁界を利 用する為に 3 相コイルが不規則な配置をしているため, 不 平衡の他に誘起電圧の高調波が懸念される。そこで誘起電 圧の高調波分析結果を図 11 に示す。図 11 より高調波はス

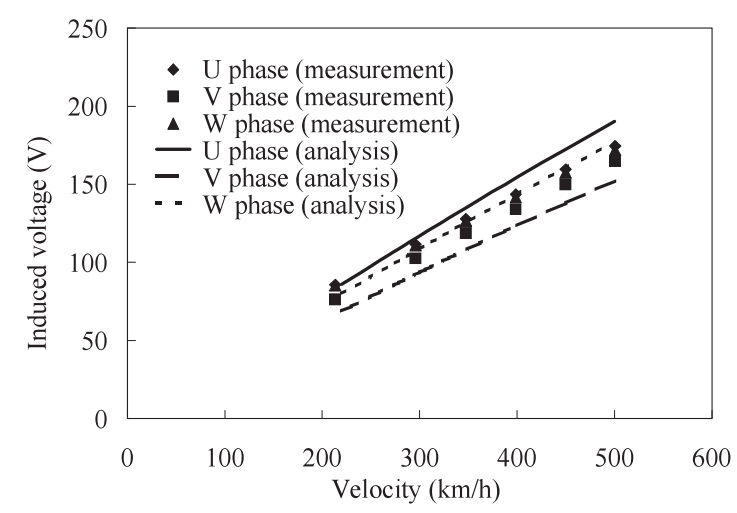

図 9 誘起電圧の速度特性

Fig. 9. Relationship between velocity and induced voltage.

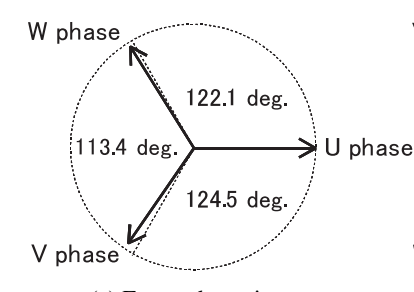

(a) Forward running

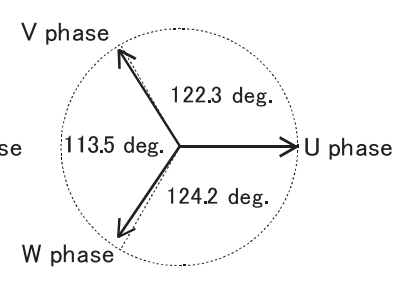

(b) Reverse running
図 10 誘起電圧のベクトル図

Fig. 10. Vector diagram of induced voltage. 


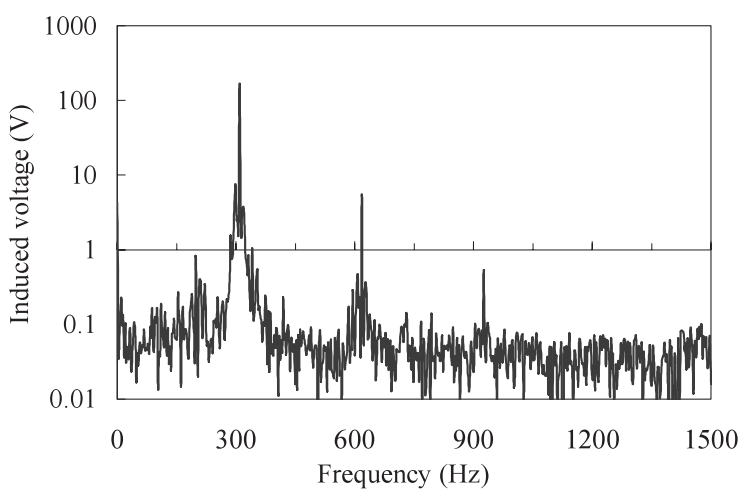

図 11 誘起電圧の高調波スペクトラム（U 相 · $500 \mathrm{~km} / \mathrm{h}$ )

Fig. 11. Harmonics spectrum of induced voltage.

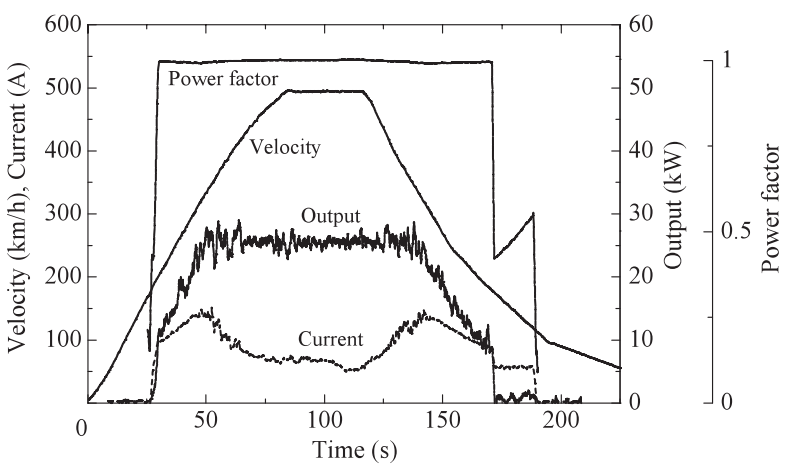

図 12 誘導集電装置の動作の様子

Fig. 12. Operation of liner generator.

ペクトラムの大きなものから順に 2 次, 3 次成分であり，そ の含有率は最大でも5\%以内で問題ないことが確認された。

（2）集電性能 図12 に積車条件における集電性能 確認試験時の装置動作全体の様子を示す。ここでは振動制 御は使用していない。また, 図中の力率は 3 相の力率の平 均值を示している。走行を開始して暫くは車輪走行により 磁気的中立位置に保たれるため誘起電圧が得られないが, 浮上走行に移行すると誘起電圧が発生する。ここではコン バー夕の集電動作開始を $200 \mathrm{~km} / \mathrm{h}$ に設定しており，そこか ら瞬時電流制御による力率 1 運転を開始する。更なる速度 増加に伴い集電電力が増大するが, $300 \mathrm{~km} / \mathrm{h}$ 強で集電電力 設定值 $25 \mathrm{~kW}$ に到達すると，その後は電力を一定に保つよ うに集電回路の電流絞り达み動作を行う。空力的揚力や曲 線などの線形変化に対しても集電回路の電流を増減させる ことで電力は一定に保たれている。減速時は $200 \mathrm{~km} / \mathrm{h}$ を 境にコンバータの集電動作が終了する。その後も浮上走行 の間はコンバータ内でダイオード整流が行われる。試験の 間，集電コイルや集電コイルを取付けた超電導磁石に扔い て異常な振動や発熱はなく, 設計・取付に問題がないこと が確認された。

図 13 に積車条件に扔ける走行速度に対する集電電力特性 と各相の集電回路力率を示す。集電電力について, $300 \mathrm{~km} / \mathrm{h}$

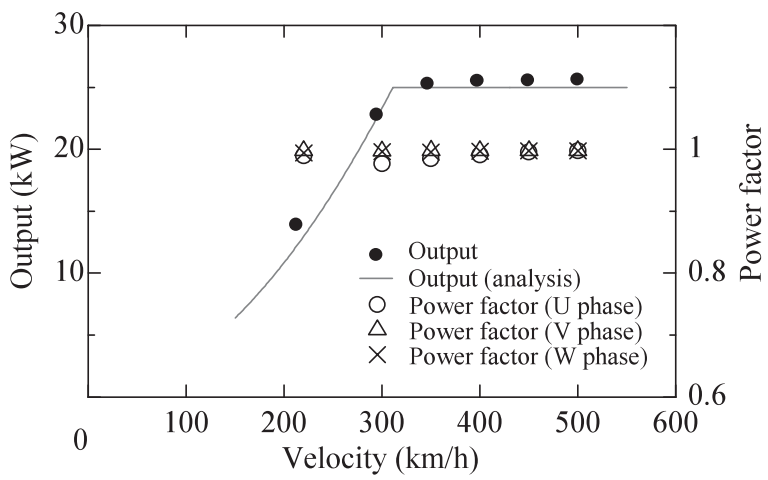

図 13 集電電力と力率の速度特性

Fig. 13. Relationship between output, power factor, and velocity.

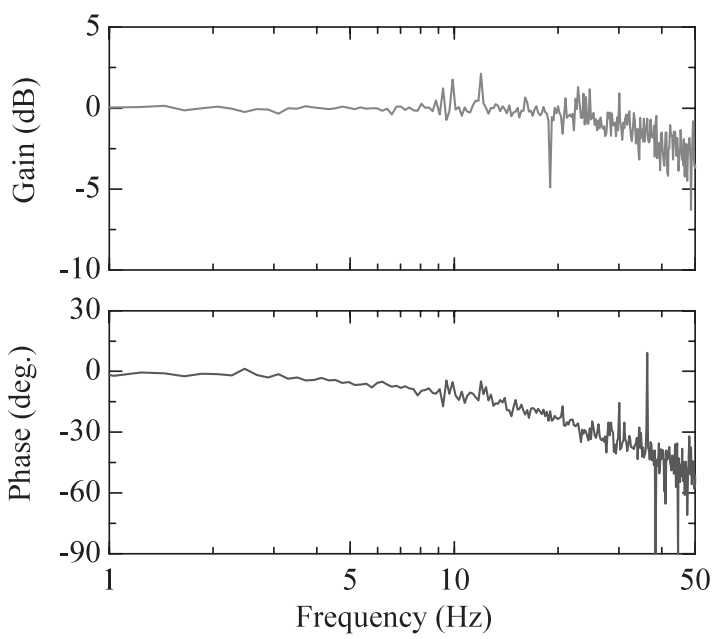

図 14 零相電流制御の応答性

Fig. 14. Response of zero-phase current control.

強において設定電力 $25 \mathrm{kw}$ に到達していることが確認でき る。計算値と測定值を比較すると全体的にほぼ一致してい る。尚, 計算值は誘起電圧の解析值（図 9）と集電コイル の抵抗值から求めた。力率についてはリアクタンスの異な る各相毎に全速度域に扔いて 0.98 以上が達成されているこ とが確認できる。

（3）振動制御零相電流により振動制御を行うに際 し，零相電流 PI 制御系の応答性を実走行にて確認した。 図 14 にゲインー周波数特性及び位相一周波数特性を示す。 これらよりゲイン特性は $20 \mathrm{~Hz}$ 程度迄ほほ $100 \%$, 位相特 性は周波数の増加に対し $1 \mathrm{deg} . / \mathrm{Hz}$ 遅れ程度であり, 実走 行体系に招いて台車振動（一次系サスの共振周波数は 4 $6 \mathrm{~Hz}$ 程度）を制御するに十分な応答性を有することが確認 された。

図 15 に $500 \mathrm{~km} / \mathrm{h}$ 走行時に集電動作と同時に振動制御 を行った場合の各種波形を示す。これは零相電流最大值を $100 \mathrm{~A}$ に設定した例である。クーロン摩擦として電磁力を 発生している零相電流出力と，また，振動制御の間も集電 電力が安定して設定值 $(25 \mathrm{~kW})$ に保たれている様子が確 


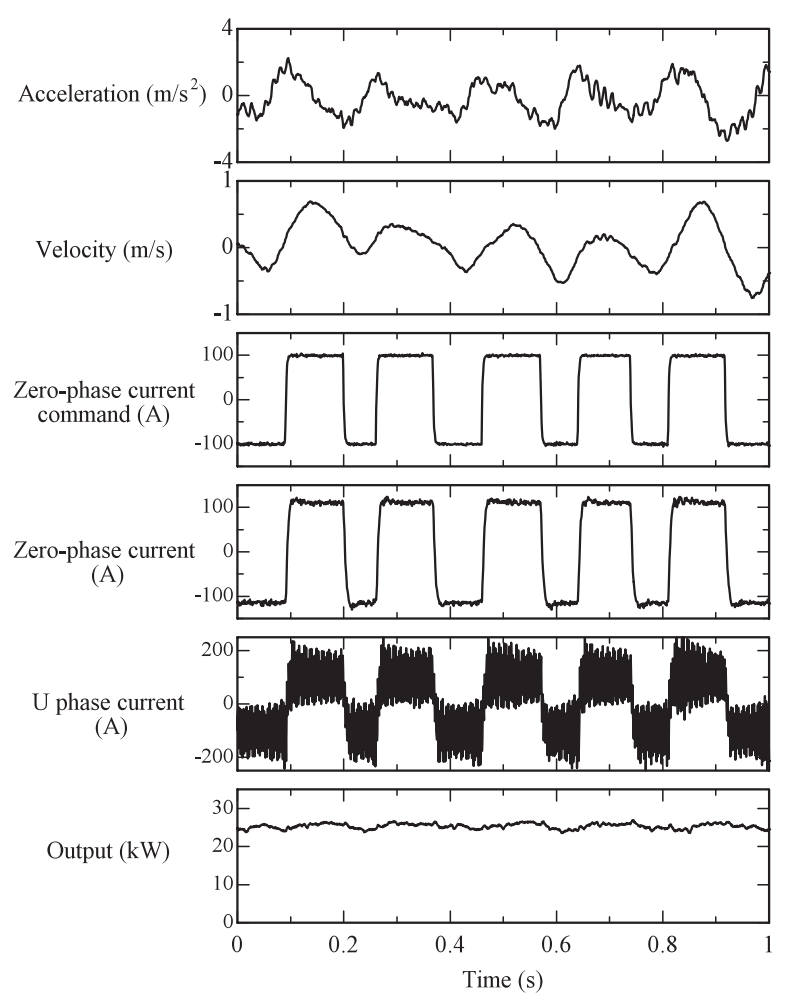

図 15 振動制御の動作波形

Fig. 15. Wave forms of vibration control.

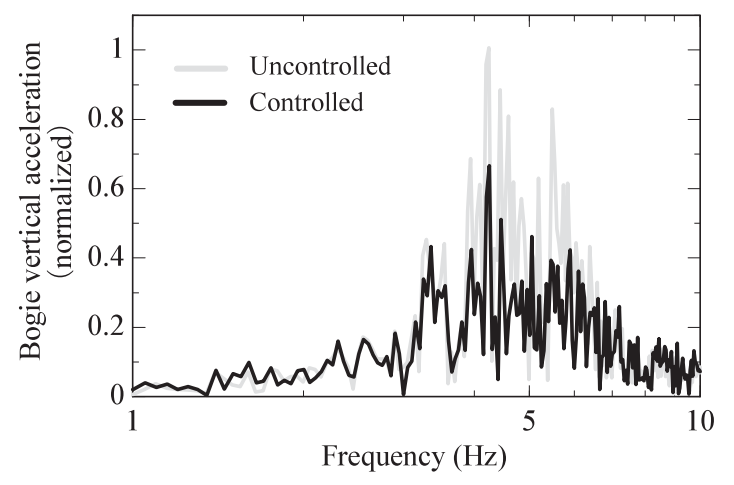

図 16 振動制御の効果

Fig. 16. Effect of vibration control.

認できる。

図 16 に台車振動低減効果の例を示す。図 16 は通常（振 動制御不使用）の振動加速度スペクトラムの最大值で規格 化している。振動制御を用いることにより $4 \sim 6 \mathrm{~Hz}$ 付近の 振動が低減している。これより誘導式磁気浮上による 1 次 系サスの共振周波数付近に大きな効果があり，その周波数 带域で振動振幅を約 6 割低減できることが実証された。

ここで，振動制御併用に必要な車上エネルギーについて 調べる。設定集電電力 $25 \mathrm{~kW}$ に到達前の速度 $(300 \mathrm{~km} / \mathrm{h})$ と到達後の速度 $(500 \mathrm{~km} / \mathrm{h})$ の各々について, 零相電流大 きさに対する集電電力を図 17 に示す。 $25 \mathrm{~kW}$ に到達前の $300 \mathrm{~km} / \mathrm{h}$ では零相電流の増加に対し集電電力が減少してい る。この減少分が振動制御に必要なエネルギーに該当する。

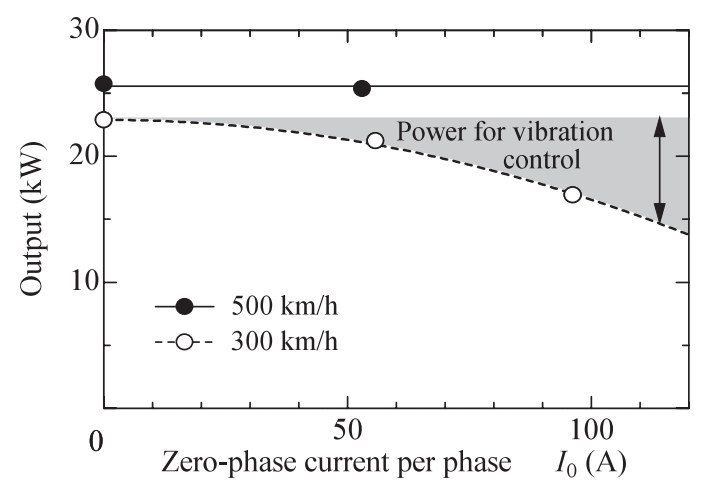

図 17 振動制御のエネルギー

Fig. 17. Energy for vibration control.

零相電流 $100 \mathrm{~A}$ に対し約 $6 \mathrm{~kW}$ であり, これは零相電流に

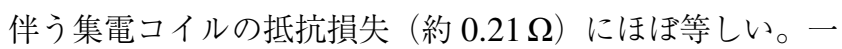
方, $25 \mathrm{~kW}$ 到達後の $500 \mathrm{~km} / \mathrm{h}$ では零相電流の増加に対して 集電電力減少は見られない。振動制御に必要なエネルギー として集電回路に誘起された $25 \mathrm{~kW}$ を超過する余剩電力が 充当され，実質的な集電能力低下に至らないことが実証さ れた。

\section{4. まとめ}

超電導磁気浮上式鉄道の車上電源候補であると同時に磁 気ダンピング発生機能を兼備した零相電流方式分散型誘導 集電装置の開発を行ってきた。今回，本装置の実用性を検 証するため，実際の車両に試験装置を搭載し，現車試験に 供した。その結果, 以下の結果を得た。

（1）誘起電圧の大きさはほぼ設計值と一致した。また, 振幅不平衡, 位相不平衡, 高調波含有率ともに $5 \%$ 以内で あり，それぞれ問題なかった。

（2）実際の誘起電圧と車上負荷を用いた系でも各相毎 に力率 1 制御 (0.98 以上) が達成された。零相電流制御の 応答性も十分であった。

（3）目標集電電力 $25 \mathrm{~kW}$ に到達する速度は積車条件で $300 \mathrm{~km} / \mathrm{h}$ 強であった。

（4）集電動作と振動制御を併用しても，安定した集電 電力が得られた。

（5）振動制御を用いることにより，台車振動振幅が約 6 割低減した。2 次系サスの効果が期待できない 1 次系サ ス (磁気浮上系) の共振周波数付近に大きなダンピング効 果があった。

（6）振動制御に必要な車上エネルギーは重畳する零相 電流に伴う集電コイル抵抗損失に等しい。また，必要速度 を超えると余利電力利用により集電性能低下は現れない。

今回の現車試験により零相誘導集電装置の車上電源とし ての成立性，また， 1 次系サスの振動制御装置としての有 用性が実証された。

最後になりましたが，試験を実施するにあたり多大なる ご支援を頂いた，日立製作所殿，東洋電機製造殿，東海旅 
客鉄道株式会社殿に感謝致します。尚，この研究の一部は

国土交通省の国庫補助金を受けて行われた。

(平成 17 年 3 月 25 日受付，平成 17 年 9 月 7 日再受付)

\section{文献}

(1) T. Murai, H. Hasegawa, and S. Fujiwara: "Improvement of Inductive Power Collection in Null-Flux EDS Maglev", Trans. IEE Japan, Vol.117-D, No.1, pp.81-90 (1997-1) (in Japanese)

村井敏昭・長谷川 均・藤原俊輔：「側壁浮上方式に扮ける誘導集電 の特性改善」, 電学論 D, 117, 1, pp.81-90 (1997-1)

(2) S. Fujiwara, T. Murai, and H. Hasegawa: "Magnetic Damping Method of EDS System Using Power Collection Coil", Trans. IEE Japan, Vol.119-D, No.2,pp.254-259 (1999-2) (in Japanese)

藤原俊輔・村井敏昭・長谷川 均:「誘導式磁気浮上での集電コイル を利用する磁気ダンピング」, 電学論 D, 119, 2, pp.254-259 (1999-2)

(3) T. Murai, H. Hasegawa, T. Yamamoto, and S. Fujiwara: "Active Magnetic Damper Using Linear Generator", Trans. IEE Japan, Vol.119-D, No.11, pp.1371-1376 (1999-11) (in Japanese)

村井敏昭・長谷川 均・山本貴光・藤原俊輔：「誘導集電装置を利用し たアクティブ磁気ダンパ」,電学論 D, 119,11,pp.1371-1376 (1999-11)

(4) H. Hasegawa, T. Murai, and T. Yamamoto: "Running Tests of Combined SC Type Linear Generator", Trans. IEE Japan, Vol.123-D, No.2, pp.156163 (2003-2) (in Japanese)

長谷川 均・村井敏昭・山本貴光：「分散型誘導集電装置の現車試験 による特性確認」, 電学論 D, 123, 2, pp.156-163 (2003-2)

(5) M. Tanaka, T. Murai, T. Yamamoto, H. Hasegawa, T. Kashiwagi, and Y. Sakamoto: "Development of Linear Generator Coils Controlling Zero-Phase Current for a Superconducting Maglev", IEEJ Technical Meetings on Linear Drives, LD-04-29 (2004-1) (in Japanese)

田中 実 ·村井敏昭 - 山本貴光 - 長谷川 均 - 柏木隆行 · 坂本泰明 : 「超電導リニア用零相方式集電コイルの開発」,電気学会リニアドラ イブ研資, LD-04-29 (2004-1)

(6) IEEE: IEEE Standard Dictionary of Electrical and Electronics Terms, p.729, Maruzen (1991)

(7) T. Watanabe, H. Ueno, N. Takeuchi, S. Nagabuchi, H. Hayashi, and Y Saitou: "PWM Converter Using Instantaneous Current Detection for Linear Generator of Maglev Vehicle”, Trans. IEE Japan, Vol.115-D, No.3, pp.348353 (1995-3) (in Japanese)

渡邊朝紀 - 上野裕久 - 竹内典子 - 永㴊澄夫 - 林 英喜 - 斉藤克忠： 「瞬時電流検出による浮上式鉄道車両誘導集電用 PWM コンバータ」, 電学論 D, 115, 3, pp.348-353 (1995-3)

(8) H. Hasegawa, T. Murai, T. Yamamoto, and E. Watanabe: "Analysis of PWM Converter for Linear Generator Controlling on Zero-Phase Current", IEEJ Technical Meetings on Linear Drives, LD-02-118 (2002-12) (in Japanese) 長谷川 均・村井敏昭・山本貴光・渡辺英司：「零相電流制御誘導集電 装置の電磁解析」, 電気学会リニアドライブ研資, LD-02-118 (2002-12)

坂 本 泰 明 (正員) 1976 年 5 月 12 日生。 2001 年 3 月九州 大学大学院システム情報科学研究科電気電子シス テム工学専攻修士課程修了。同年 (財) 鉄道総合 技術研究所入所。2005 年 4 月東海旅客鉄道（株） へ出向, 現在に至る。主としてリニアモータの研 究, 開発に従事。

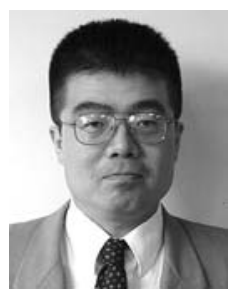

正員） 1964 年 11 月 30 日生。 1989 年 3 月早稲 田大学大学院理工学研究科修士課程電気工学専攻 修了。同年 (財) 鉄道総合技術研究所入所。2005 年 4 月東海旅客鉄道（株）へ移籍，現在に至る。 主としてリニアモータ, 磁気浮上の研究, 開発に 従事。工博。

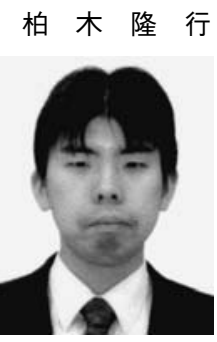

（正員） 1971 年 4 月 4 日生。1997 年 3 月早稲田 大学大学院理工学研究科修士課程電気工学専攻修 了。同年 (財) 鉄道総合技術研究所入所，現在に 至る。主として超電導磁気浮上式鉄道技術の在来 方式鉄道への応用に関する研究，開発に従事。

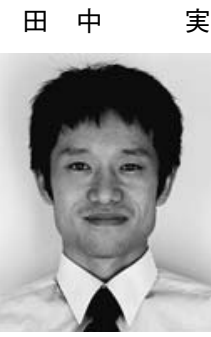

（正員） 1972 年 10 月 11 日生。 2000 年 3 月豊 橋技術科学大学大学院工学研究科博士後期課程電 子・情報工学専攻修了。同年（財）鉄道総合技術 研究所入所, 現在に至る。主としてリニアモータ 用コイルの研究，開発に従事。工博。

鈴 木 江里光 (非会員) 1966 年 11 月 23 日生。 1994 年 3 月八

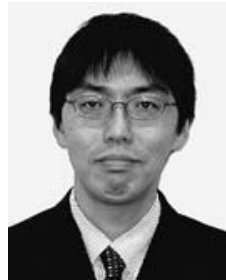
ワイ大学大学院工学研究科機械工学専攻修士課程 修了。同年 (財) 鉄道総合技術研究所入所。2005 年 4 月東海旅客鉄道 (株) 一出向, 現在に至る。主 として車両運動の研究に従事。日本機械学会会員。

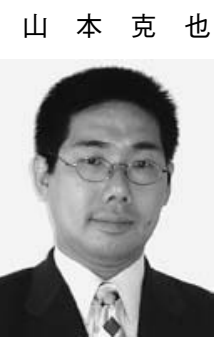

(非会員) 1967 年 2 月 8 日生。 1990 年 3 月東 京都立大学工学部機械工学科卒業。同年（財）鉄 道総合技術研究所入所，現在に至る。主としてア クティブ消音の研究，開発に従事。日本機械学会 会員。 